\title{
Disability retirement among university public servants: epidemiological profile and causes
}

\author{
Aposentadoria por invalidez de servidores públicos universitários: perfil epidemiológico e causas \\ Jubilación por invalidez de funcionarios públicos universitarios: perfil epidemiológico y causas
}

\begin{abstract}
Aline Aparecida Oliveira Moreira', Júlia Trevisan Martins', Maria Lucia do Carmo Cruz Robazzi", Renata Perfeito Ribeiro"I", Maria do Carmo Fernandez Haddad Lourenço ${ }^{\text {III, }}$ Maria Ribeiro Lacerda ${ }^{\text {Iv }}$

' Universidade Estadual de Londrina, Postgraduate Program in Nursing. Londrina, Paraná, Brazil.

"Universidade de São Paulo, Ribeirão Preto College of Nursing. Ribeirão Preto, São Paulo, Brazil.

II' Universidade Estadual de Londrina, Center for Health Sciences, Department of Nursing. Londrina, Paraná, Brazil. Iv Universidade Federal do Paraná, Health Sciences Sector, Nursing Department. Curitiba, Paraná, Brazil
\end{abstract}

How to cite this article:

Moreira AAO, Martins JT, Robazzi MLCC, Ribeiro RP, Lourenço MCFH, Lacerda MR. Disability retirement among university public servants: epidemiological profile and causes. Rev Bras Enferm [Internet]. 2018;71(2):289-96.

DOI: http://dx.doi.org/10.1590/0034-7167-2016-0653

Submission: 12-08-2016 Approval: 04-14-2017

\section{ABSTRACT}

Objective: To identify the epidemiological profile and causes of disability pensions for university public servants. Method: A crosssectional and descriptive study, carried out with 40 retired employees due to disability of a public university. Sociodemographic, occupational and clinical data were obtained. The analyses were stratified according to gender, considering a significance level of $5 \%$. Results: Disability pensions were more frequent among women $(72.5 \%)$, aged up to 60 years $(77.5 \%)$. Mental and behavioral disorders were mainly responsible for pensions (35\%). There was a significant difference between the sexes ( $p$ $\leq 0.05)$ for the variables: educational level, function performed by the worker and presence of dependents. Conclusion: The epidemiological profile showed a higher frequency of female, married/stable marital status, aged between 51 and 60 years and up to 12 years of schooling. Chronic degenerative diseases were predominant among the causes for disability pensions.

Descriptors: Retirement; Disability Insurance; University; Workers; Worker's Health.

\section{RESUMO}

Objetivo: Identificar o perfil epidemiológico e as causas das aposentadorias por invalidez de servidores públicos universitários. Método: Estudo transversal e descritivo, realizado com 40 servidores aposentados por invalidez de uma universidade pública. Foram obtidos dados sociodemográficos, ocupacionais e clínicos. As análises foram estratificadas segundo o sexo, considerando nível de significância de 5\%. Resultados: As aposentadorias por invalidez foram mais frequentes entre as mulheres $(72,5 \%)$, com idade de até 60 anos $(77,5 \%)$. As doenças mentais e comportamentais foram as principais responsáveis pelas aposentadorias $(35 \%)$. Constatou-se diferença significativa entre os sexos $(p \leq 0,05)$ para as variáveis: escolaridade, função exercida pelo trabalhador e presença de dependentes. Conclusão: O perfil epidemiológico mostrou maior frequência do sexo feminino, estado civil casado/união estável, com idade entre 51 e 60 anos e até 12 anos de estudo. As doenças crônicas degenerativas foram predominantes entre as causas das aposentadorias por invalidez.

Descritores: Aposentadoria; Seguro por Invalidez; Universidade; Trabalhadores; Saúde do Trabalhador.

\section{RESUMEN}

Objetivo: Identificar el perfil epidemiológico y las causas de las jubilaciones por invalidez de funcionarios públicos universitarios. Método: Estudio transversal y descriptivo, realizado con 40 funcionarios jubilados por invalidez de una universidad pública. Fueron obtenidos datos socio demográficos, ocupacionales y clínicos. Los análisis fueron estratificados según el sexo, considerando nivel de significancia de $5 \%$. Resultados: Las jubilaciones por invalidez fueron más frecuentes entre las mujeres $(72,5 \%)$, con edad hasta 60 años $(77,5 \%)$. Las enfermedades mentales y conductoales fueron las principales responsables por las jubilaciones $(35 \%)$. Se constató diferencia significativa entre los sexos $(p \leq 0,05)$ para las variables: escolaridad, función 
ejercida por el trabajador y presencia de dependientes. Conclusión: El perfil epidemiológico mostró mayor frecuencia del sexo femenino, estado civil casado/unión estable, con edad entre 51 y 60 años y hasta 12 años de estudio. Las enfermedades crónicas degenerativas fueron predominantes entre las causas de las jubilaciones por invalidez.

Descriptores: Jubilación; Seguro por Invalidez; Universidad; Trabajadores; Salud del Trabajador.

\section{INTRODUCTION}

Work presents a diversity of meanings and significance, often ambiguous, such as the association with suffering, subsistence, identity and social recognition ${ }^{(1)}$.

From the Marxist perspective, work can be understood in two ways: the first, in relation to man's action on nature to satisfy his needs; in the second, vital and creative labor is transformed into commodity and alienation, and the labor force responds to the imperious needs of the capitalist world ${ }^{(2)}$.

The economic system adopted by capitalism caused changes in the productive sphere, mainly related to technology; yet progress has not helped to alleviate the work process. On the contrary, it has increased demands on the worker, in that he needs to adjust to the technological apparatus, since the focus is to produce more in less time. The intensification of workforce exploitation has a direct impact on the health of the worker through the occurrence of accidents and physical and mental illnesses ${ }^{(3)}$.

Considering Brazilian public institutions, the employees, in order to carry out their activities and respond to their public mission, face inefficient, bureaucratic and inconsistent organizational functioning, and the social condition of the population served also contributes to difficulty in achieving success in the workplace, despite individual engagement of workers. The recurrence of these problems in the public service routine, coupled with the high work load and intensity related to the scarcity of inadequate material, human and local resources, culminates in the loss of work sense and consequently mental and physical illness due to this persistent fatigue ${ }^{(4)}$.

Thus, work activity can cause temporary or permanent occupational incapacity, the latter being responsible for leading workers to fall back upon the social security system.

The Brazilian social security system is divided into three categories: General Social Security Regime (RGPS), Social Security Regimes (RPPS) and Complementary Pension Plans. The RGPS is intended for private sector workers, military personnel, public servants, as well as members of the Judiciary, Legislative and Executive Powers that contribute to the National Institute of Social Security (INSS). RPPS are assigned to statutory public servants, organized and maintained by states and municipalities. The voluntary supplementary pension plan is made by means of an additional contribution to the INSS or by people employed by banks to obtain supplementary retirement benefits ${ }^{(5)}$.

Among the four types of retirement offered by the Social Security to the insured are due to disability, granted to insured workers who become permanently incapacitated due to sickness or accident in service, and after proof by expert medical examination. The proceeds are proportional to the employee's contributions, except in the event of an occupational accident, occupational disease or serious, transmissible or incurable disease $^{(6)}$

The State of Paraná adopts the RPPS called Paraná Previdência, which was established by State Law No. 12,398, dated December 30, 1998, and follows the same parameters as previously cited for the granting of disability pensions ${ }^{(7)}$.

In Brazil, the incidence of disability pensions has grown over the years and affects economically active workers who have insufficient social security contributions. The main causes of permanent incapacity to work are cardiovascular, musculoskeletal and mental diseases ${ }^{(8)}$.

In terms of conceding new benefits, over 500,000 disability pensions were granted in the RGPS during the period from 2012 to 2014, resulting in an average of over 188,000 new benefits per year ${ }^{(9)}$. Thus, in addition to the impact of disability retirement on the worker and employer, there are important repercussions on the social security system itself.

In view of the above, and due to the fact that there are few studies on the subject of disability retirement, especially among public university employees ${ }^{(10)}$, it is necessary to deepen the issues related to the disability retirement of these employees, since it will help managers such as: rectory, deanship, direction of centers, department heads, among others, together with workers, to carry out planning and implement measures that promote health, by prevention of the risks present in the work environments, aiming at the protection of health, reduction in injuries and, consequently, improving their quality of life.

Thus, this study aimed to identify the epidemiological profile and causes of disability pensions for university public servants.

It should be emphasized that disability retirement and its relationship with the health of the worker were configured as the object of this investigation from the final outcome, that is, the diseases or injuries that caused the employees disability retirement of a public higher education institution.

\section{METHOD}

\section{Ethical aspects}

The research was submitted to the Research Ethics Committee Involving Human Beings of the State University of Londrina (UEL) and approved. All the participants signed the Free and Informed Consent Term.

\section{Design, place of study and period}

A cross-sectional and descriptive study was carried out at UEL from January to June 2016. This university was recognized in 1971 and consists of 17,858 students, 1,650 faculty members and 3,433 technical-administrative staff, with 9 study centers and 15 academically linked supplementary 
institutions, among which are the University Hospital and the Ambulatory of Specialties ${ }^{(11)}$.

This research is part of a larger project titled "Quality of life of civil servants retired from public universities in Paraná", developed by the Núcleo de Estudo da Saúde do Trabalhador da UEL (Nuestuel) [UEL Worker Health Study Center].

\section{Population, inclusion and exclusion criteria}

The population was composed of all employees retired due to disability at that university in the period from 2000 to 2014, identified through a list provided by the Pro-Rector of Human Resources of the institution. Inclusion criteria were considered: both sexes; to have been a public servant under a statutory regime; reside in the city or metropolitan region of the study; be retired for at least one year; and to have the cognitive ability to respond to the questionnaires.

\section{Study protocol}

Retirees were contacted and invited to participate in the survey by telephone and electronic media (e-mail and social networks). Subsequent to the invitation, meetings were scheduled for application of the questionnaires.

The data were collected by the principal researcher from January to June 2016, through a questionnaire prepared by her and that met the objectives of the study, having previously conducted a pilot test with a population similar to that of the study, in order to verify the understanding of the questionnaire and operationalization of the collection.

The questionnaire contained questions related to the cause of disability retirement (illness or injury for which the worker was retired) and epidemiological profile (sociodemographic, occupational, and clinical data). The sociodemographic data included the following variables: age, sex, marital status, educational level, number of dependents and family income. Regarding the occupational variables, the following were collected: the year of retirement, the function they performed, the length of service in the university. The clinical variables were: the presence of selfreported comorbidities (depression, arterial hypertension, musculoskeletal diseases, stroke, cancer, arthritis, diabetes mellitus, heart disease, dyslipidemia and psychiatric diseases).

It is underscored that the sociodemographic, occupational and clinical variables used in this research to describe the epidemiological profile were understood as defining a population that involves health related conditions, including diseases, life habits, use of medications in specific populations, age, sex, marital status, among others ${ }^{(12)}$.

The illness or injury for which the worker was retired due to disability was subsequently classified according to the International Classification of Diseases and Related Health Problems version ten $(\mathrm{ICD}-10)^{(13)}$.

\section{Analysis of results and statistics}

The data processing was performed in Microsoft Excel, with double typing. Verification of the consistency of the information was carried out by Epi Info, version 3.5.2. After this process, the data were exported to Statistical Package for the Social Sciences (SPSS), version 20.0, for analysis. Descriptive analyses were performed with the presentation of absolute and relative frequencies for the categorical variables.

Analyses were stratified by sex; for this, a re-categorization of the variables that were not dichotomic was carried out, the education level was classified into up to 8 years of study and more than 9 years of study, the position was divided into operational and others, the associations were verified by application of Chi-square or Fischer's exact test, in cases where the expected frequency was less than five. The strength of association was verified by Cramer's $\vee$ test. A significance level of $5 \%$ was considered for all tests.

\section{RESULTS}

Of the 88 public employees retired due to disability identified by the University's Human Resources sector, 30 had already died. 58 remained eligible for this survey. Of these, 13 were excluded because they did not meet the inclusion criteria: residing in the city and/or metropolitan region of the study (12) and cognitive inability to respond to the questionnaire (1), in addition to five refusals.

The participants of this study were 40 retirees due to invalidity, $29(72.5 \%)$ female and $11(27.5 \%)$ male. As to age, 11 $(27.5 \%)$ were up to 50 years old, $20(50 \%)$ were between 51 and 60 years old and $9(22.5 \%)$ were older than 61 years. In relation to marital status, the majority declared themselves to be married or in stable union ( $\mathrm{n}=27,67.5 \%), 7$ (17.5\%) divorced, $4(10 \%)$ widowed and 2 (5\%) unmarried. When mentioning schooling, a significant number of retirees ( $\mathrm{n}=14,35 \%$ ) had between 9 and 12 years of schooling, followed by 13 to 16 years ( $\mathrm{n}=12,30 \%), 10(25 \%$ and only $4(10 \%)$ reported more than 17 years of study. The family income was mainly between 4 and 10 minimum wages ( $n=20,50 \%), 15(37.5 \%)$ declared up to 3 minimum wages (the Brazilian minimum wage corresponded to $\mathrm{R} \$ 880.00$ in August, 2016). Most retirees reported supporting dependents on their income $(n=26,65 \%)$.

When analyzing the functions performed at the university before retirement, $14(35 \%)$ of the retired individuals were in general services, $13(32.5 \%)$ were in the nursing area (nursing auxiliary and technician), 6 (15\%) worked as secretaries, $3(7.5 \%)$ were teachers and $4(10 \%)$ were grouped in others (university agent, technician and violinist), since the first two reported the positions and not the function performed.

Regarding the length of service in the institution, the minimum was 3 years and the maximum of 33 years, with a median of 15 years (SD $=7.250), 7(17.5 \%)$ worked up to 10 years at the university, $29(72.5 \%)$ between 11 and 25 years and $4(10 \%)$ over 26 years.

As for the time participants were retired, $24(60 \%)$ reported up to 9 years and 16 (40\%) over 10 years, with 16 years being the maximum stated.

With regard to the causes of disability leave, these are presented in Table 1.

The sex-stratified comorbidities are presented in Table 2. Regarding medication use, most ( $\mathrm{n}=36,90 \%$ ) reported continuous use, with up to four daily medications being the most frequent $(\mathrm{n}=27,67.5 \%)$. 
Table 1 - Causes of disability pensions for public university employees $(n=40)$, Londrina, Paraná, Brazil, 2016

\begin{tabular}{lcc}
\hline \multirow{2}{*}{ Causes of retirement } & \multicolumn{2}{c}{ Sex } \\
\cline { 2 - 3 } & Female & Male \\
\cline { 2 - 3 } & $\mathbf{n ~ ( \% )}$ & $\mathbf{n ~ ( \% )}$ \\
\hline \multirow{2}{*}{ Mental and behavioral disorders } & $11(78.6)$ & $3(21.4)$ \\
Musculoskeletal diseases & $9(90.0)$ & $1(10.0)$ \\
Circulatory system diseases & $3(50.0)$ & $3(50.0)$ \\
External causes (traumatism) & $1(25.0)$ & $3(75.0)$ \\
Cancer' & $3(100)$ & - \\
Others" & $2(66.6)$ & $1(33.3)$ \\
\hline
\end{tabular}

Note: 'Cerebral, breast, medulla. "Multiple sclerosis, leprosy, and Parkinson's.

Table 2 - Comorbidities according to gender in disability retirement among employees of a public university ( $n=40)$, Londrina, Paraná, Brazil, 2016

\begin{tabular}{|c|c|c|c|}
\hline \multirow{2}{*}{ Comorbidities } & \multicolumn{2}{|c|}{ Sex } & \multirow{2}{*}{$\begin{array}{c}p \\
\text { value }\end{array}$} \\
\hline & $\begin{array}{c}\text { Female } \\
\text { n (\%) }\end{array}$ & $\begin{array}{l}\text { Male } \\
\text { n (\%) }\end{array}$ & \\
\hline \multicolumn{4}{|l|}{ Depression } \\
\hline Yes & $14(82.4)$ & $3(17.6)$ & 0.230 \\
\hline No & $15(65.2)$ & $8(34.8)$ & \\
\hline \multicolumn{4}{|c|}{ Arterial Hypertension } \\
\hline Yes & $10(66.7)$ & $5(33.3)$ & 0.522 \\
\hline No & $19(76.0)$ & $6(24.0)$ & \\
\hline \multicolumn{4}{|l|}{ Musculoskeletal } \\
\hline Yes & $13(86.7)$ & $2(13.3)$ & 0.120 \\
\hline No & $16(64.0)$ & $9(36.0)$ & \\
\hline \multicolumn{4}{|c|}{ Cerebral vascular accident } \\
\hline Yes & $4(57.1)$ & $3(42.9)$ & 0.316 \\
\hline No & $25(75.8)$ & $8(24.2)$ & \\
\hline \multicolumn{4}{|l|}{ Cancer } \\
\hline Yes & $6(85.7)$ & $1(14.3)$ & 0.389 \\
\hline No & $23(69.7)$ & $10(30.3)$ & \\
\hline \multicolumn{4}{|l|}{ Arthritis } \\
\hline Yes & $2(40.0)$ & $3(60.0)$ & $0.117^{*}$ \\
\hline No & $27(77.1)$ & $8(22.9)$ & \\
\hline \multicolumn{4}{|c|}{ Diabetes mellitus } \\
\hline Yes & $4(80.0)$ & $1(20.0)$ & 0.688 \\
\hline No & 25 (71.4) & $10(28.6)$ & \\
\hline
\end{tabular}

Note: *Fischer's Exact Test.

Table 3 - Distribution of the variables significantly associated with sex in employees retired due to disability at a public university $(n=40)$, Londrina, Paraná, Brazil, 2016

\begin{tabular}{|c|c|c|c|c|}
\hline \multirow{2}{*}{ Variable } & Female & Male & \multirow{2}{*}{$\begin{array}{c}\text { Cramer's } \\
\mathbf{V}^{*}\end{array}$} & \multirow{2}{*}{$\underset{\text { value }}{p}$} \\
\hline & n (\%) & n (\%) & & \\
\hline \multicolumn{5}{|c|}{ Schooling in years } \\
\hline$\leq 8$ & $3(30.0)$ & $7(70.0)$ & \multirow{3}{*}{0.550} & \multirow{3}{*}{0.001} \\
\hline$>8$ & $26(86.7)$ & $4(13.3)$ & & \\
\hline Function & & & & \\
\hline General services & $6(42.9)$ & $8(57.1)$ & \multirow{2}{*}{0.487} & \multirow{2}{*}{0.002} \\
\hline Others & $23(88.5)$ & $3(11.5)$ & & \\
\hline \multicolumn{5}{|l|}{ Has dependents } \\
\hline Yes & $16(61.5)$ & $10(38.5)$ & \multirow{2}{*}{0.335} & \multirow{2}{*}{0.034} \\
\hline No & $13(92.9)$ & $1(7.1)$ & & \\
\hline
\end{tabular}

Note: * Cramer's V Test
The sociodemographic and occupational variables that obtained statistical significance $(p \leq 0.05)$ after re-categorization were: schooling, university function and dependents in the family. Educational level was the variable that presented the greatest strength of association, as shown in Table 3.

\section{DISCUSSION}

Although the deaths of retirees due to disability were not the object of analysis in the present investigation, it is worth mentioning that mortality among this population is little known; however, a study carried out in Brazil found that the younger the worker is when prevented from working due to disability, the more likely they are to evolve to death; as the years receiving benefits pass, the more the probability of death decreases. Neoplasms present a $50 \%$ chance of death within the first year of retirement. Among disability retirees, women have better life expectancies compared to men ${ }^{(14)}$.

In the present study, disability retirement was more frequent among women. These results were also identified in national and international surveys that indicate that they are related to the double day that most women experience, that is, work activities plus domestic activities. This increases their overload, stress and health problems, by the consequent reduction in time for leisure and health care, especially for promotion and prevention ${ }^{(15-20)}$.

Regarding the marital status variable, most of the studies are performed with secondary data from the social security systems, in which this variable is often not registered. In research carried out with retirees from a public university in Rio de Janeiro, there was a higher frequency of married individuals among the retirees due to alcoholism and this was not seen in those receiving pensions due to general disability ${ }^{(17)}$. This differs from the present investigation, in which a significant number of people reported living with a partner. This fact is salutary, since people who maintain affective bonds and social relationships are more likely to increase well-being and, in turn, quality of life.

In this study, disability pensions affected workers still in their productive age, data that are analogous to other research with disability pensioners ${ }^{(10,17)}$. This fact has an impact on the Brazilian pension system, which presents a historic deficit; among the many factors, is the diversion of funds and noncompliance with budget laws ${ }^{(21)}$, as well as in financial deficits to workers who often did not reach the necessary retirement time for full retirement benefits. However, it should be noted that these retirees are the breadwinner of their family and dependents, such as children, grandchildren, nephews, among others, impacting not only the life of the individual, but also an entire family ${ }^{(16)}$.

Regarding the years of schooling, disability retirement is granted more frequently among people with schooling up to high school, corresponding to 12 years of study, and is directly related to work activities, such as: stricter routines and greater physical effort ${ }^{(22)}$. Lower schooling and predominantly physical work was a finding of the present study, since the majority of the retired exercised the function of general services.

Nursing professionals corresponded to the second largest number of disability pensions; this may be related to work activities, in which they are exposed in their work environments 
to biological, psychological, physiological, mechanical, physical and chemical burdens. Nursing workers have high rates of absenteeism throughout the work process, and temporary leave is evolving into permanent retirements, that is, often into early retirements ${ }^{(23)}$. It is evident that management actions are needed to reduce the negative effects of the work environment on the health of nursing professionals, as well as the need for these workers to be aware of the problems arising from the work environment and to use strategies to reduce the impact on their health.

With regard to income there is no single pension scheme, but rather the combination of a series of schemes and subschemes with their own characteristics and varying impacts on the income of retirees; thus, public servants who are retired due to disability generally have lower incomes than those found in the present study ${ }^{(24)}$. The salary difference can be explained by the population of public servants with career plans and positions established that contribute to increase the salary income by means of additional courses. In addition, the maximum salary paid by the National Institute of Social Security (INSS) is lower than that of Paraná Previdência ${ }^{(9,25)}$.

When considering the working time in the institution, it is noted that the expressive majority did not reach the required contribution period; however, it was not possible to verify if the workers collected a social security contribution prior to that of the university. However, by relating this data to the time of retirement of these people, one can observe early exit from the labor market, since the age was predominantly below 60 years and several employees had more than 10 years of retirement, inferring social security contributions smaller than that required, implying proportional benefits, with direct repercussions on the life of the individual, society and social security ${ }^{(17)}$.

Among the main causes that contribute to incapacity for work are chronic noncommunicable diseases (NCD), which can occur in a transitory or definitive way, generating early retirements. Circulatory system diseases (CAD), musculoskeletal diseases (MSD), cancers and mental and behavioral disorders (MBD) are the ones most related to disability retirement, data that corroborate the findings of the present study ${ }^{(10,26)}$. Such diseases can be avoided and it is the responsibility of workers, together with the employers and managers, to institute actions to promote health in the workplace, prevention and identification of risk factors for NCDs.

It is a fact that work activities, for the most part, are surrounded by factors that provoke overload among workers, such as: extensive workload, strenuous work rhythms, conflicting interpersonal relationships, unhealthy environments, among others. These factors can compromise the health status of people, leading them to develop mainly MSD, CAD, pulmonary diseases and MBD ${ }^{(27)}$ and, consequently leading to early retirements.

A study in Norway on the causes of disability retirement has identified the prevalence for $\mathrm{MBD}^{(18)}$. Another investigation carried out in Sweden also with disability pensioners showed a predominance of mental illness ${ }^{(20)}$.

In research carried out with Swedes, the data showed that work in the area of health, social service or military service, as well as presenting high labor demands are risk factors for mental illness, regardless of family factors, and these diseases are the main reasons for invalidity retirement in that country ${ }^{(28)}$.
Another investigation carried out in 15 cities in Finland between 2000 and 2011, with 3,943 workers, identified that 476 were retired due to disability, of which $23.6 \%$ were related to MBD and $38.4 \%$ to musculoskeletal disorders. In the present study, when correlating the morbidities present in these individuals at the beginning of follow-up, the authors concluded that diseases of the musculoskeletal system and MBD constitute strong predictors for early retirement ${ }^{(29)}$.

It is emphasized that the aggravations that led to definitive retirement, that is, in the disability pensions in the present study, are similar to those found in another Brazilian investigation ${ }^{(16)}$, in which MBD was the first cause $(22.6 \%)$, second was MSD $(14.8 \%)$, CAD the third cause $(13.8 \%)$ and cancer the fourth cause $(11.9 \%)$. The latter finding was different from the present study, in cancer ranked in fifth place. It is believed that this difference may be related to mortality from this aggravation, which is the second cause of death in the country ${ }^{(30)}$. Considering that this research was conducted from interviews with retirees and a high death rate was identified, without the possibility of defining the reason for retirement, unlike the other Brazilian study ${ }^{(16)}$, which was performed through secondary data. Regarding external causes, although they did not find a prominent cause of disability in the studies, they are responsible for the third cause of Brazilian mortality, especially among men ${ }^{(30)}$.

It is also noted that psychiatric disorders affect younger workers and present an increasing incidence as a reason for incapacity to work $^{(16,31)}$. Studies on the Brazilian Social Security benefits with emphasis on retirement due to mental illness have identified that $6.2 \%$ of the concessions for mental illness are work related ${ }^{(32)}$. These data are worrisome, since the work is aimed at subsistence, and generally connotes the identity of the individual and not so much suffering, to the point of becoming irreversibly ill.

Research has identified that the occurrence of mental disorders and cardiovascular diseases is associated with work overload, with younger workers being affected mainly by $M B D^{(33)}$. Yet, in a systematic review study, he identified that psychological harassment, high demands and low labor control, imbalance in work environment between effort and reward, low relational and procedural justice, stress, and poor social support in the workplace present as risk factors for depression, anxiety, and work-related stress ${ }^{(34)}$.

The risk factors listed can be identified in the work of the public servant, where in spite of the stability of employment, they experience shortages of human and material resources, causing overload and accumulation of functions, bureaucratic and hierarchical management, as well as uncertainties regarding the transition of governments ${ }^{(35)}$.

It is noted in the present investigation that the frequency of comorbidities also contributed to the disability pensions, since they were consequences of health problems presented by the interviewees, that is to say, it was possible to identify the existence of other diseases besides those that cause disability in the retired, even the vast majority of participants self-report making continuous use of medications. The highest frequency of NCD among females was also identified in a population survey conducted in Brazil in 2013(36); however, 
the higher frequency of arthritis among men found in this study is contrary to the literature, which reports a higher prevalence among women ${ }^{(37)}$.

The results of this study confirm the impact of NCD on disability pensions and the need for programs to improve workers' health as measures to identify the risk factors for chronic diseases, in order to awaken the worker to harmful habits. especially since people dispense medical care for a variety of reasons, such as lack of time, difficulty accessing health services, and signs and symptoms that do not interfere with their immediate daily lives ${ }^{(38)}$.

The association analysis showed a significant difference between the sexes, with men having the lowest level of schooling, which is also directly related to the general services function, which requires mainly physical activities, with little control over work, besides these workers receiving the lowest salaries of the university employees. The Brazilian Institute of Geography and Statistics (IBGE) describes this fact as conforming to the Brazilian reality, in which women have a better level of education ${ }^{(39)}$.

The majority of disability retirees reported having dependents in the family. Although the $\mathrm{IBGE}^{(39)}$ found that men continue to be the main providers in the family, there was a higher frequency among retired women reporting the existence of dependents. This fact, together with the socioeconomic condition, can also represent a pressure experienced by the retirees, given their responsibility as a provider together with their personal leisure needs, health care, and the purchase of medications to control NCDs ${ }^{(40)}$.

\section{Study limitations}

As a limitation of the study, its transverse character is pointed out, since this does enable the establishment of cause and effect; another factor refers to the low number of retirees that were still alive, as this may have caused the disparity with other studies and may also have interfered in the identification of other associations in this population.

\section{Contributions to the area of Nursing, health or public policy}

It is believed that this study is of singular importance, since it contributed to the identification of early retirement due to disability and the associated factors that can be used by the managers and employees in the planning of actions directed at improving the worker's health in order to reduce the risks factors for disability.

\section{CONCLUSION}

The epidemiological profile of the disability pensioners in this study was characterized by the female gender, married or in a stable union, aged between 51 and 60 years, with up to 12 years of schooling and with financial dependents. The function performed among employees before retirement was mainly related to general services.

Regarding the causes of disability retirement, chronic degenerative diseases, as well as mental and behavioral diseases, musculoskeletal system, circulatory system and cancer, besides external causes, were the main reasons for the definitive retirement from work.

The results also allowed us to conclude that there were significant differences between the sexes, which are mainly associated with lower schooling and the functional category in which physical work is more intense, this may be a health risk factor among males.

\section{REFERENCES}

1. Borges LO, Yamamoto OH. Mundo do trabalho: construção histórica e desafios contemporâneos. In Zanelli JC, Borges-Andrade JE, Bastos AVB(Orgs.). Psicologia, organizações e trabalho no Brasil. Porto Alegre: Artmed, 2014. p. 25-72.

2. Marx K. O capital: crítica da economia política. Livro I. Processo de produção do capital. São Paulo: Boitempo; 2013.

3. Lara R. Saúde do trabalhador: considerações a partir da crítica da economia política. Rev Katálysis [Internet]. 2011 [cited 2017 Apr 04];14(1):78-85. Available from: http://www.scielo.br/pdf/rk/v14n1/v14n1a09.pdf

4. Jackson Filho JM. Engajamento no trabalho, impedimentos organizacionais e adoecer: a contribuição da Ergonomia da Atividade no setor público brasileiro. Rev Bras Saúde Ocup[Internet]. 2015 [cited 2017 Apr 04];40(131):98-108. Available from: http:// www.scielo.br/pdf/rbso/v40n131/0303-7657-rbso-40-131-98.pdf

5. Santos MF. Direito Previdenciário esquematizado. 8 ed. São Paulo: Saraiva; 2012.

6. Pinto SM. Legislação Previdenciária. 19.ed. São Paulo: Atlas; 2013.

7. Paraná. Resolução 218, de 22 de outubro de 2014. Dispõe sobre o Plano de Benefício do Regime Próprio de Previdência Social dos Servidores do Estado do Paraná [Internet]. Curitiba: 2014 [cited 2016 Sep 01]. Available from: http://www.paranaprevidencia. pr.gov.br/modules/documentos/get_file.php?curent_file $=1745 \&$ curent_dir $=1284$

8. Gomes MMF, Figoli MG, Ribeiro AJF. Da atividade à invalidez permanente: um estudo utilizando dados do Regime Geral de Previdência Social (RGPS) do Brasil no período 1999-2002. Rev Bras Estud Popul [Internet]. 2010 [cited 2016 Sep 01];27(2):297316. Available from: http://www.scielo.br/pdf/rbepop/v27n2/05.pdf

9. Brasil. Ministério da Previdência Social. MPS/INSS/DATAPREV. Anuário Estatístico da Previdência Social, vol 14 [Internet]. MS: Brasília; 2014 [cited 2016 Sep 01]. Available from: http://www.previdencia.gov.br/wp-content/uploads/2016/07/AEPS-2014.pdf

10. Santos TR, Silva Júnior WR, França ISX, Cavalcanti AL, Fernandes MGM. Perfil socioeconômico-demográfico do beneficiário do Instituto Nacional do Seguro Social aposentado por invalidez e suas causas, no Estado da Paraíba, no quinquênio $2007-2011$. 
Rev Bras Estud Popul[Internet]. 2012 [cited 2016 Sep 06];29(2):349-59. Available from: http://www.scielo.br/pdf/rbepop/v29n2/ a08v29n2.pdf

11. Universidade Estadual de Londrina. Diretoria de Avaliação e Acompanhamento Institucional da Pró-Reitoria de Planejamento - PROPLAN. UEL em dados 2015 [Internet]. Londrina; 2015 [cited 2016 Sep 10]. Available from: http://www.uel.br/com/ agenciaueldenoticias/fotos/UELEMDADOS2015.pdf

12. Porta $M(E d$.$) . A dictionary of epidemiology. 6$ ed. Nova York: Oxford University Press; 2014.

13. Organização Mundial da Saúde. Classificação Internacional de Doenças e Problemas Relacionados com a Saúde (CID-10) [Internet]. 10.ed.rev. São Paulo: OMS; 2008 [cited 2016 Oct 01]. Available from: http://www.datasus.gov.br/cid10/V2008/cid10.htm

14. Ribeiro AJF, Figoli MGB, Sawyer DO, Cesar CC. Tábuas de mortalidade dos aposentados por invalidez pelo Regime Geral da Previdência Social - 1999-2002. Rev Bras Estud Popul [Internet]. 2007 [cited 2016 Sep 05]; 24(1): 91-108. Available from: http:// www.scielo.br/pdf/rbepop/v24n1/06.pdf

15. Almeida GFP, Ribeiro MHA, Silva MACN, Branco RCC, Pinheiro FCM, Nascimento MDSB. Patologias osteomusculares como causa de aposentadoria por invalidez em servidores públicos do município de São Luís, Maranhão. Rev Bras Med Trab[Internet]. 2016 [cited 2016 Sep 20];14(1):37-44. Available from: http://files.bvs.br/upload/S/1679-4435/2016/v14n1/a5452.pdf

16. Santos ACQ, Limongi JE, Jorge MLMP, Jorge MT, Pereira BB, Jorge PT. Aposentadorias por invalidez e Doenças Crônicas entre os servidores da Prefeitura Municipal de Uberlândia, Minas Gerais, 1990-2009. Cad Saúde Colet[Internet]. 2015 [cited 2016 Sep 01];23(1):57-62. Available from: http://www.scielo.br/pdf/cadsc/v23n1/1414-462X-cadsc-23-01-00057.pdf

17. Brites RMR, Abreu AMM, Pinto JESS. Prevalência de alcoolismo no perfil das aposentadorias por invalidez dentre trabalhadores de uma universidade federal. Rev Bras Enferm[Internet]. 2014 [cited 2016 Sep 01];67(3):373-80. Available from: http://www. scielo.br/pdf/reben/v67n3/0034-7167-reben-67-03-0373.pdf

18. Gjerde LC, Knudsen GP, Czajkowski N, Gillespie N, Aggen SH, Røysamb E, et al. Genetic and environmental contributions to longterm sick leave and disability pension: a population-based study of young adult norwegian twins. Twin Res Hum Genet[Internet]. 2013 [cited 2016 Sep 20];16(4):1-16. Available from: https://www.ncbi.nlm.nih.gov/pmc/articles/PMC3800163/ DOI 10.1017/ thg.2013.36

19. Halford C, Wallman T, Welin L, Rosengren A, Bardel A, Johansson S, et al. Effects of self-rated health on sick leave, disability pension, hospital admissions and mortality: a population-based longitudinal study of nearly 15,000 observations among Swedish women and men. BMC Public Health[Internet] 2012 [cited 2016 Sep 03];12(1103):1-11. Available from: http://bmcpublichealth. biomedcentral.com/articles/10.1186/1471-2458-12-1103

20. Narusyte J, Ropponen A, Silventoinen K, Alexanderson K, Kaprio J, Samuelsson A, et al. Genetic liability to disability pension in women and men: a prospective population-based twin study. PLos ONE [Internet] 2011 [cited 2016 Sep 04];6(8):1-8. Available from: https://www.ncbi.nlm.nih.gov/pmc/articles/PMC3151284/DOI: 10.1371/journal.pone.0023143

21. Silva LL, Costa TMT. A formação do sistema previdenciário brasileiro: 90 anos de história, vol. 8. Viçosa: Administração Pública e Gestão Social; 2016.

22. Polvinen A, Laaksonen M, Gould R, Lahelma E, Martikainen P. The contribution of major diagnostic causes to socioeconomic differences in disability retirement. Scand J Work Environ Health. [Internet] 2014 [cited 2016 Sep 30];40(4):353-60. Available from: http://www.sjweh.fi/show_abstract.php?abstract_id=3411 DOI 10.5271/sjweh.3411

23. Mininel VA, Felli VEA, Silva EJ, Torri Z, Abreu AP, Branco MTA. Workloads, strain processes and sickness absenteeism in nursing. Rev Latino-Am Enfermagem [Internet]. 2013[cited 2016 Oct 07];21(6):1290-1297. Available from: http://www.scielo.br/pdf/rlae/ v21n6/0104-1169-rlae-21-06-01290.pdf

24. Medeiros M, Souza PHGF. Previdências dos trabalhadores dos setores público e privado e desigualdade no Brasil. Econ Apl[Internet]. 2014 [cited 2016 Oct 1];18(4):603-23. Available from: http://www.scielo.br/pdf/ecoa/v18n4/02.pdf

25. Paraná. Decreto- lei № 18.493, de 24 de junho de 2015. Anexo I da resolução nº 04279/2016. Tabela de vencimento básico e remuneração[Internet]. Curitiba; 2015 [cited 2016 Sep 29]. Available from: http://www.portaldoservidor.pr.gov.br/arquivos/ File/2016/TabelasSalariais2016.pdf

26. Alcantara MA, Nunes GS, Ferreira BCMS. Distúrbios osteomusculares relacionados ao trabalho: o perfil dos trabalhadores em benefício previdenciário em Diamantina (MG, Brasil). Ciênc Saúde Colet [Internet]. 2011[cited 2016 Sep 27];16(8):3427-36. Available from: http://www.scielo.br/pdf/csc/v16n8/a10v16n8.pdf

27. Santana LL, Miranda FM D'A, Karino ME, Baptista PCP, Felli VEA, Sarquis LMM. Description of workloads and fatigue experienced among health workers in a teaching hospital. Rev Gaúcha Enferm [Internet]. 2013[cited 2016 Oct 07];34(1):64-70. Available from: http://www.scielo.br/pdf/rgenf/v34n1/en_08.pdf

28. Samuelsson $\AA$, Ropponen A, Alexanderson K, Svedberg P. Psychosocial working conditions, occupational groups, and risk of disability pension due to mental diagnoses: a cohort study of 43,000 Swedish twins. Scand J Work Environ Health [Internet]. 2013[cited 2016 Sep 28];39(4):351-60. Available from: http://www.sjweh.fi/show_abstract.php?abstract_id = 3338

29. Kaila-Kangas L, Haukka E, Miranda H, Kivekäs T, Ahola K, Luukkonen R, et al. Common mental and musculoskeletal disorders as predictors of disability retirement among Finns. J Affect Disord[Internet] 2014[cited 2016 Sep 25];165:38-44. Available from: https://www.ncbi.nlm.nih.gov/pubmed/24882175 
30. Brasil. Ministério da Saúde. Secretaria de Vigilância em Saúde. Saúde Brasil 2013: uma análise da situação de saúde e das doenças transmissíveis relacionadas à pobreza [Internet]. Brasília: Ministério da Saúde; 2014 [cited 2016 Oct 01]. Available from: http://bvsms.saude.gov.br/bvs/publicacoes/saude_brasil_2013_analise_situacao_saude.pdf

31. Brasil. Ministério da Previdência Social. Acompanhamento mensal dos benefícios auxílios-doença previdenciários, concedidos segundo os códigos da CID-10 [Internet]. 2016 [cited 2016 Sep 16]. Available from: http://www.previdencia.gov.br/wp-content/ uploads/2016/08/cid10_2016.01-05_prev.pdf

32. Silva Junior JS, Fischer FM. Disability due to mental illness: social security benefits in Brazil 2008-2011. Rev Saúde Pública [Internet]. 2014[cited 2016 Sep 07];48(1):186-90. Available from: http://www.scielo.br/pdf/rsp/v48n1/en_0034-8910-rsp-48-01-0186.pdf

33. Yamauchi T, Yoshikawa T, Takamoto M, Sasaki T, Matsumoto S, Kayashima K, et al. Overwork-related disorders in Japan: recent trends and development of a national policy to promote preventive measures. Ind Health [Internet]. 2017 [cited 2017 Feb 23]. Available from: https://www.jstage.jst.go.jp/article/indhealth/advpub/0/advpub_2016-0198/_article

34. Harvey SB, Modini M, Joyce S, Milligan-Saville JS, Tan L, Mykletun A, et al. Can work make you mentally ill? a systematic metareview of work-related risk factors for common mental health problems. Occup Environ Med [Internet]. 2017[cited 2017 Feb 23]. Available from: http://oem.bmj.com/content/early/2017/01/20/oemed-2016-104015

35. Nunes AVL, Lins SLB. Servidores públicos federais: uma análise do prazer e sofrimento no trabalho. Rev Psicol Organ Trab [Internet]. 2009 [cited 2017 Feb 23];9(1):51-67. Available from: http://pepsic.bvsalud.org/pdf/rpot/v9n1/v9n1a04.pdf

36. Theme Filha MM, Souza Junior PRB, Damacena GN, Szwarcwald CL. Prevalence of chronic non-communicable diseases and association with self-rated health: National Health Survey, 2013. Rev Bras Epidemiol[Internet]. 2015[cited 2016 Sep 23];18(Suppl-2):83-96. Available from: http://www.scielo.br/pdf/rbepid/v18s2/en_1980-5497-rbepid-18-s2-00083.pdf

37. Mota LMH, Cruz BA, Brenol CV, Pereira IA, Fronza LSR, Bertolo MB, et al. 2011 Consensus of the Brazilian Society of Rheumatology for diagnosis and early assessment of rheumatoid arthritis. Rev Bras Reumatol[Internet]. 2011 [cited 2016 Oct 2];51(3):207-19. Available from: http://www.scielo.br/pdf/rbr/v51n3/en_v51n3a02.pdf

38. Hyeda A, Costa ESM, Sbardellotto F, Ferreira JCC. A aplicação da arquitetura de informação na gestão dos riscos das doenças crônicas em trabalhadores: uma análise preliminar. Rev Bras Med Trab[Internet]. 2016 [cited 2016 Oct 02];14(1):29-36. Available from: http://files.bvs.br/upload/S/1679-4435/2016/v14n1/a5451.pdf

39. Brasil. Instituto Brasileiro de Geografia e Estatística (IBGE). Estatísticas de gênero: uma análise dos resultados do censo demográfico 2010 [Internet]. Rio de Janeiro, 2014 [cited 2016 Sep 29]. Available from: http://biblioteca.ibge.gov.br/visualizacao/livros/ liv88941.pdf

40. Geib LTC. Determinantes sociais da saúde do idoso. Ciênc Saúde Colet[Internet]. 2012[cited 2016 Oct 06];17(1):123-33. Available from: http://www.scielo.br/pdf/csc/v17n1/a15v17n1.pdf 